\title{
Proximal composition and fatty acid profile of Hemigrapsus crenulatus (H. Milne Edwards, 1837) as one of the main foods of "patagonian blenny"Eleginops maclovinus (Cuvier, 1830)
}

\author{
G. Figueroa-Muñoz ${ }^{a, b, c}$ (D), P. De los Ríos-Escalante ${ }^{d, e}$ (D), P. Dantagnan ${ }^{a, f}$ (D), C. Toledo ${ }^{g}$ (D),

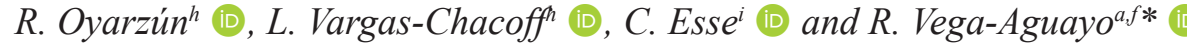

aUniversidad Católica de Temuco, Facultad de Recursos Naturales, Departamento de Ciencias Agropecuarias y Acuícolas, Temuco, Chile

'Ilustre Municipalidad de Cisnes, Puerto Cisnes, Chile

'Universidad de Concepción, Facultad de Ciencias Naturales y Oceanográficas, Departamento de Zoología, Genomics in Ecology, Evolution and Conservation Laboratory - GEECLAB, Concepción, Chile

dUniversidad Católica de Temuco, Facultad de Recursos Naturales, Departamento de Ciencias Biológicas y Químicas, Temuco, Chile

eUniversidad Católica de Temuco, Núcleo de Estudios Ambientales, Temuco, Chile

fUniversidad Católica de Temuco, Núcleo de Investigación en Producción Alimentaria, Temuco, Chile

'Universidad Católica de Temuco, Facultad de Recursos Naturales, Programa de Doctorado en Ciencias Agropecuarias, Temuco, Chile

${ }^{\text {h} U n i v e r s i d a d ~ A u s t r a l ~ d e ~ C h i l e, ~ F o n d o ~ d e ~ F i n a n c i a m i e n t o ~ d e ~ C e n t r o s ~ d e ~ I n v e s t i g a c i o ́ n ~ e n ~ A ́ r e a s ~ P r i o r i t a r i a s-~ F O N D A P, ~}$ Centro de Investigación Dinámica de Ecosistemas Marinos de Altas Latitudes-IDEAL, Instituto de Ciencias Marinas y Limnológicas, Valdivia, Chile

iUniversidad Autónoma de Chile, Facultad de Arquitectura y Construcción, Instituto de Estudios del Hábitat - IEH, Unidad de Cambio Climático y Medio Ambiente - UCCMA, Temuco, Chile

*e-mail: rvega@uct.cl

Received: December 05, 2019 - Accepted: April 07, 2020 - Distributed: August 31, 2021

\begin{abstract}
The Patagonian blenny (Eleginops maclovinus) is species endemic to South America with physiological characteristics that would facilitate its incorporation into Chilean aquaculture. However, there is currently no specific artificial food that can be used to raise E. maclovinus. In light of this problem, this study describes the proximal composition and fatty acid profile of the crab Hemigrapsus crenulatus, one of the main foods of E. maclovinus. The purpose of the study is to serve as basic information for the development of a specific artificial diet for juveniles of this fish species. The proximal analysis of the complete body of $H$. crenulatus indicates that it is mainly composed of ash (35.9\%), proteins $(32.2 \%)$, glucides $(19.8 \%)$ and minor lipids $(3.6 \%)$. The fatty acid profile is $40.7 \%$ PUFAs, $29.7 \%$ MUFAs and 29.5\% SAFAs, and the most abundant acids are Eicosapentaenoic (18.8\%), Oleic (6.8\%) and Palmitic (16.6\%), respectively. H. crenulatus has highest level of proteins, lipids and PUFAs among the species of the Brachyura infraorder.
\end{abstract}

Keywords: Eleginops maclovinus, Hemigrapsus crenulatus, proximal analysis, fatty acid profile.

\section{Composição proximal e perfil de ácidos graxos de Hemigrapsus crenulatus (H. Milne Edwards, 1837) como um dos principais alimentos da "blenny patagônica" Eleginops maclovinus (Cuvier, 1830)}

\section{Resumo}

O "blenny da patagônia" (Eleginops maclovinus) é uma espécie endêmica da América do Sul, com características fisiológicas que facilitariam sua incorporação na aquicultura chilena. No entanto, atualmente não há alimento artificial específico que possa ser usado para criar E. maclovinus. Diante desse problema, este estudo descreve a composição proximal e o perfil de ácidos graxos do caranguejo Hemigrapsus crenulatus, um dos principais alimentos de E. maclovinus. O objetivo do estudo é servir como informação básica para o desenvolvimento de uma dieta artificial específica para espécies juvenis desse peixe. A análise proximal do corpo completo de H. crenulatus indica que ele é composto, principalmente, de cinzas $(35,9 \%)$, proteínas $(32,2 \%)$, glicídios $(19,8 \%)$ e lipídios menores $(3,6 \%)$. O perfil 
de ácidos graxos é 40,7\% PUFA, 29,7\% MUFA e 29,5\% SAFA, e os ácidos mais abundantes são eicosapentaenoico $(18,8 \%)$, oleico $(6,8 \%)$ e palmítico $(16,6 \%)$, respectivamente. H. crenulatus possui o mais alto nível de proteínas, lipídios e PUFAs entre as espécies da infraordem de Brachyura.

Palavras-chave: Eleginops maclovinus, Hemigrapsus crenulatus, análise proximal, perfil de ácidos graxos.

\section{Introduction}

Chile is undergoing an aquaculture diversification process that has led to increased public and government interest in promoting the development of aquaculture of native species with the potential for cultivation (Sa et al., 2014) such as Eleginops maclovinus (Cuvier, 1830). E. maclovinus is a monotypic species from the Eleginopsidae family that is endemic to the southern part of South America (VargasChacoff et al., 2014; Ceballos et al., 2016). Its geographic distribution ranges are from the mouth of the Plata River to the extreme south of South America on the Atlantic Coast, including the Falkland Islands, and from there to Valparaíso on the Pacific Coast (Gacitúa et al., 2008). It can be found in environments with different levels of salinity, including the open sea, coastal waters, estuaries and freshwater rivers (Pequeño, 1979; Vargas-Chacoff et al., 2016). In regard to its ecology, this species, which presents bento-demersal habits, is an important component of many trophic chains in the areas that it inhabits as both predator and prey. As a predator, it is an omnivore with a generalist, opportunistictype diet, feeding mainly on crustaceans, polychaetes, insects and marine algae (Guzmán and Campodónico, 1973; Pavés et al., 2005; Licandeo et al., 2006; Martin and Bastida, 2008; Pequeño et al., 2010; Figueroa-Muñoz and De los Ríos, 2018; De los Ríos et al., 2019). Its stomach contents have been found to include a wide variety of food items such as the intertidal crab Hemigrapsus crenulatus (H. Milne Edwards, 1837), which has been described as one of its most frequent and abundant preys in terms of biomass (Licandeo et al., 2006). It has also been described as the exclusive prey of the fish (Figueroa-Muñoz and De Los Ríos, 2018).

H. crenulatus is an epibenthic species from estuary habitats in the South Pacific Ocean. It is found in Chile between Cavancha Beach in Iquique to the north and the Strait of Magellan and in New Zealand (Retamal, 1969; Retamal and Moyano, 2010; Urbina et al., 2010; McLay et al., 2011). It is a euryhaline estuary marine species of tropical origin from temperate environments that tolerates broad temperature fluctuations ( 6 to $24{ }^{\circ} \mathrm{C}$ ) (Cumillaf et al., 2016) and salinity. Most of the adults are excellent osmoregulators that can grow in a wide range of salinities between 5 to 33\%o (Urbina et al., 2010; Urzúa and Urbina, 2017).

The advantages of developing the breeding of E. maclovinus in Chile include the fact that it is an endemic white meat species, presents a high rate of growth in the natural environment, ranges from $10.2-11 \mathrm{~cm}^{\text {year }}{ }^{-1}$ for cohorts in the Atlantic Ocean (Gosztonyi, 1974; Brickle et al., 2005) and $6.4 \mathrm{~cm}$ year $^{-1}$ for a cohort from the Pacific Ocean (Licandeo et al., 2006), has a high tolerance for captivity (Vargas-Chacoff et al., 2014) with limited antagonistic behavior (Sa et al., 2014), presents a high rate of fertilization and high fecundity as well as low mortality rates for larvae and juveniles in captivity (Sa et al., 2014; Valdebenito Isler et al., 2016, 2018), has omnivorous feeding habits (Pequeño et al., 2010), tolerates variations in temperatures and salinity (Vargas-Chacoff et al., 2016; Oyarzún et al., 2018) and accepts pelletized feed in a feral manner (Fortt et al., 2007; Buschmann et al., 2009), facilitating one of the main challenges to be resolved at the beginning of the breeding of native fish (Deguara, 1997). However, a priority challenge is the development of specific artificial diets for the different stages of its ontogenetic development. There is no information on many of its nutritional requirements, as only the protein requirements of juveniles have been determined. According to Sa et al. (2014), this corresponds to $10 \%$ to satisfy its metabolic needs and $35 \%$ to optimize growth. Additionally, for juveniles of E. maclovinus a proximal composition has been reported, with a percentage of protein levels in the range of 54.29-60.66, lipids of 28.17-36.51, ash of 8.799.46, and energy of 25.93-27.83 (Oyarzún et al., 2019). This information can be used as a reference range for diet-specific design for E. maclovinus. However, currently the information for the design of diets for this species is still very limited.

Given these circumstances, there is a need to obtain basic information on the nutritional composition of $H$. crenulatus the main prey of E. maclovinus in the wild, particularly fatty acids, as it has been determined that these molecules are the main energy source that the fish use for their growth and reproduction. They also fulfill a structural function, forming part of the phosphoglycerides of cellular membranes (Sargent et al., 2002). Furthermore, long chain omega 3 such as docosahexaenoic acid (DHA 22:6n-3) and eicosapentaenoic acid (EPA 20:5n-3) in marine fish are considered to be essential to survival and normal growth and development (Tocher, 2010).

The aim of this study is to describe the proximal composition and fatty acid profile of the crab $H$. crenulatus in order to contribute to research on its nutrition and potentially to develop of artificial diet to E. maclovinus diet.

\section{Material and Methods}

\subsection{Capture of H. crenulatus specimens}

The capture was carried out in the intertidal area of Puerto Cisnes bay $\left(44^{\circ} 44 \mathrm{~S} 72^{\circ} 41 \mathrm{~W}\right)$ during the winter of 2017 (Vega-Aguayo et al., 2018). The H. crenulatus specimens were gathered manually at random during low tide under rocks until at least $700 \mathrm{~g}(\mathrm{~N}=406)$ of wet weight sample had been collected. The specimens were then frozen 
at $-20{ }^{\circ} \mathrm{C}$ and sent to the Universidad Católica de Temuco Fish Physiology and Nutrition Laboratory for analysis.

\subsection{Determining the proximal composition of H. crenulatus}

The analysis was conducted at the Universidad Católica de Temuco Fish Physiology and Nutrition Laboratory in duplicate following AOAC methods (AOAC, 1995). The sample was first lyophilized at $-48{ }^{\circ} \mathrm{C}$ at a pressure of 3 mbar. The researchers then determined the dry material by gravimetric at $104{ }^{\circ} \mathrm{C}$ for $24 \mathrm{~h}$, the crude protein using the Kjeldahl technique ( $\mathrm{N}$ x 6.25), the total lipid content (ethereal extract) using the gravimetric method of extracting fats with a Soxhlet device using petroleum ether $\left(40-60^{\circ}\right)$, the ash content using burning of the sample at $550{ }^{\circ} \mathrm{C}$ for three hours in order to obtain inorganic content, the crude fiber by acid hydrolysis of the defatted samples with sulfuric acid $\left(\mathrm{H}_{2} \mathrm{SO}_{4}\right)$, followed by alkaline hydrolysis with potassium hydroxide $(\mathrm{KOH})$ in a digestion system and using a Fibertec device (AOAC, 1993), the carbon glucides or hydrates (non-nitrogenized extract) by difference, phosphorus using Mission Reaction AOAC method 965.17 and gross energy using mathematical calculation following Maynard et al. (1979).

\subsection{Determination of the fatty acid profile of H. crenulatus}

The analysis was conducted in the Universidad Católica de Temuco Fish Physiology and Nutrition Laboratory using the methodology described by Dantagnan et al. (2012). The samples were lyophilized and the total lipids were extracted using a blend of methanol chloroform (2:1) (Folch et al., 1957). The fatty acids were methylated using the model proposed by Morrison and Smith (1964) and separated using a Hewlett Packard 5890 Series II Plus gas chromatograph (Wilmington NC, USA), with a capillary column measuring $30 \mathrm{~m} * 0.25 \mathrm{~mm} * 0.20 \mu \mathrm{m}$ (SP ${ }^{\mathrm{TM}}$ 2380, SUPELCO, Bellefonte, PA, USA). Helium gas was used as the transporter gas. The fatty acids were identified through comparison with a standard Supelco 37 fatty acid (Sigma Aldrich, St. Louis, MO, USA). The fatty acids were expressed on a dry basis as a percentage of the total of fatty acids identified.

\section{Results}

\subsection{Proximal composition of H. crenulatus}

The results obtained show that $H$. crenulatus is mainly composed of ash (35.88\%) and proteins (32.18\%), and to a lesser extent by glucides (non-nitrogenized extract, 19.84\%), fiber (8.5\%) and lipids (ethereal extract, 3.6\%); with gross energy of $10.25 \mathrm{MJ} \mathrm{kg}^{-1}$ (Table 1).

\subsection{Fatty acid profile of $H$. crenulatus}

The fatty acid profile of the full set of specimens of $H$. crenulatus is composed of polyunsaturated fatty acids (PUFAs), $40.7 \%$, the most abundant of which is eicosapentaenoic acid (EPA) at 18.8\%; 29.7\% monounsaturated fatty acids (MUFAs), the most abundant of which is oleic acid, $16.8 \%$, and $29.5 \%$ saturated fatty acids (SAFAs), the most abundant of which is palmitic acid, at $16.6 \%$. In regard to the PUFAs from the omega-3 series, these constituted $28.3 \%$ and the EPA/DHA ratio was 3.4, which indicates that there is more abundance of EPA than DHA (Table 2).

\section{Discussion}

\subsection{H. crenulatus as one of the main foods of E. maclovinus}

H. crenulatus has been described as prey of Eleginops maclovinus (Cuvier, 1830) in studies conducted in Chile in the estuary of the Valdivia River (Table 3). For example, Pavés et al. (2005) state that in specimens ranging from 18 to $79 \mathrm{~cm}$ in length captured during March 2002, this food item presented a frequency of occurrence $(\% \mathrm{~F})$ of 4.9 and an abundance based on the number of prey $(\% \mathrm{~N})$ of 0.008. Pequeño et al. (2010) include data from Pavés et al. (2005) and state that in specimens captured in the same area in August 2003, this food item presented a \% F of 9.1 and a $\% \mathrm{~N}$ of 0.038 . Licandeo et al. (2006) state that in fish with a total length of between 19 and $57 \mathrm{~cm}$, this food item presented a $\% \mathrm{~F}$ of 35.4 and a $\% \mathrm{~N}$ of 2.55 between November 2002 and December 2003.

The abundance of prey in the stomach depends on their abundance in the environment. Pavés et al. (2005) and Pequeño et al. (2010) showed a low $\% \mathrm{~F}$ and $\% \mathrm{~N}$ for $H$. crenulatus because the most abundant prey species in the area studied by these authors was the amphipod Paracorophium hartmannorum (Andres, 1975), which represented over $90 \%$ of individual prey in both seasons. In the area studied in this article, the most abundant species is $H$. crenulatus, which presents an ecological density of $11.50 \pm 10.62$ individuals $\mathrm{m}^{-2}$ (Vega-Aguayo et al., 2018). The results of $\% \mathrm{~F} 35.4$ and $\% \mathrm{~N} 2.55$ obtained by Licandeo et al. (2006) are the closest to our results $(\% \mathrm{~F}$ 78.7 and $\% \mathrm{~N} 96.3$ ), however this prey is so abundant in Aysén that it represents an even greater $\% \mathrm{~F}$ and $\% \mathrm{~N}$.

\subsection{Proximal composition of $H$. crenulatus}

The high quantity of ashes $(35.88 \%)$ obtained in the proximal composition (Table 1) is due to the fact that the

Table 1. Proximal composition (percentage in dry basis) of specimens of $H$. crenulatus captured at Puerto Cisnes.

\begin{tabular}{lr}
\hline Total dry matter (\%) & 96.89 \\
Crude protein (\%) & 32.18 \\
Total lipids (\%) & 3.60 \\
Crude fiber (\%) & 8.50 \\
Total ash (\%) & 35.88 \\
Glucides (\%) & 19.84 \\
Phosphorous (\%) & 0.72 \\
Gross energy (MJ kg $\left.{ }^{-1}\right)$ & 10.25 \\
\hline
\end{tabular}


Table 2. Fatty acid profile (percentage of dry basis of the total fatty acids identified) in $H$. crenulatus specimens captured at Puerto Cisnes.

\begin{tabular}{|c|c|c|}
\hline \multicolumn{2}{|c|}{ Saturated Fatty Acids (SAFAs) } & \multirow{2}{*}{$\begin{array}{c}\% \\
0.19\end{array}$} \\
\hline C12:0 & Lauric acid & \\
\hline C13:0 & Tridecanoic acid & 0.04 \\
\hline $\mathrm{C} 14: 0$ & Myristic acid & 2.60 \\
\hline $\mathrm{C} 15: 0$ & Pentadecanoic acid & 0.56 \\
\hline C16:0 & Palmitic acid & 16.59 \\
\hline $\mathrm{C} 17: 0$ & Heptadecanoic acid & 2.05 \\
\hline C18:0 & Stearic acid & 4.63 \\
\hline C20:0 & Arachidic acid & 0.22 \\
\hline $\mathrm{C} 21: 0$ & Heneicosanoic acid & 1.24 \\
\hline $\mathrm{C} 22: 0$ & Behenic acid & 0.26 \\
\hline $\mathrm{C} 23: 0$ & Tricosanoic acid & 0.66 \\
\hline $\mathrm{C} 24: 0$ & Lignoceric acid & 0.49 \\
\hline Total SAFAs & & 29.54 \\
\hline \multicolumn{3}{|c|}{ Monounsaturated fatty acids (MUFAs) } \\
\hline $\mathrm{C} 14: 1$ & Myristoleic acid & 0.53 \\
\hline C16:1 & Palmitoleic acid & 9.83 \\
\hline $\mathrm{C} 17: 1$ & cis-10-Heptadecenoic acid & 1.18 \\
\hline $\mathrm{C} 18: 1 n-9 t$ & Elaidic acid & 0.20 \\
\hline $\mathrm{C} 18: 1 n-9 c$ & Oleic acid & 16.84 \\
\hline $\mathrm{C} 20: 1 n-9$ & cis-11-Eicosenoic acid & 0.76 \\
\hline $\mathrm{C} 22: 1 n-9$ & Erucic acid & 0.09 \\
\hline $\mathrm{C} 24: 1 n-9$ & Nervonic acid & 0.27 \\
\hline Total MUFAs & & 29.74 \\
\hline \multicolumn{3}{|c|}{ Polyunsaturated fatty acids (PUFAs) } \\
\hline $\mathrm{C} 18: 2 n-6 c$ & Linoleic acid & 8.52 \\
\hline $\mathrm{C} 18: 3 n-3$ & Linolenic acid & 3.89 \\
\hline $\mathrm{C} 18: 3 n-6$ & g-Linolenic acid & 0.35 \\
\hline $\mathrm{C} 20: 2$ & cis-11,14-Eicosadienoic acid & 1.05 \\
\hline $\mathrm{C} 20: 3 n-3$ & cis-11, 14, 17-Eicosatrienoic acid & 0.13 \\
\hline $\mathrm{C} 20: 3 n-6$ & cis-8,11,14-Eicosatrienoic acid & 0.40 \\
\hline $\mathrm{C} 20: 4 n-6$ & Arachidonic acid & 2.10 \\
\hline $\mathrm{C} 20: 5 n-3$ & cis-5,8,11,14,17-Eicosapentaenoic acid & 18.77 \\
\hline $\mathrm{C} 22: 6 n-3$ & cis-4,7,10,13,16,19-Docosahexaenoic acid & 5.51 \\
\hline Total $n-3$ PUFAs & & 28.31 \\
\hline Total PUFAs & & 40.72 \\
\hline EPA/DHA & & 3.4 \\
\hline EPA + DHA & & 24.28 \\
\hline
\end{tabular}

specimen possess a broad cephalothorax that covers their entire body, which is typical of the Brachyura family. It is comprised of a large proportion of minerals (ashes) such as calcium, iron, zinc, potassium and phosphorus (Sifa et al., 2000; Adeyeye, 2002). This value is similar to the one described by García Alonso and Oviedo Vega (1990) in another species from the same family, the Cuban blue crab, Callinectes sapidus (Rathbun, 1896) (31\%) (Table 4$)$. The high percentage of proteins $(32.18 \%)$ and lipids $(3.6 \%)$ in the body compared to those described for some structures of other species from the Brachyura family is noteworthy. This amount would be much higher than many of those species, as its ranges run from 7 to
$22.6 \%$ proteins and 0.2 to $1.21 \%$ lipids. The percentage of lipids (3.6\%) would be similar to those described for Carcinus maenas (Linnaeus, 1758) (3.8\%). This species presents the highest percentage of proteins, which is $80.9 \%$ (Table 4). The percentages of proteins and lipids of the organs are generally higher than those of the musculature of the body, with ranges of 12.5 to $62.2 \%$ of proteins and 7.8 to $59.9 \%$ for lipids.

The high percentages of high quality lipids $(40.7 \%$ PUFAs) found are interesting given that $H$. crenulatus could be a potential ingredient for future formulations of diets of E. maclovinus, although more analyses are need to determine the amino acid profile and apply treatments 
Table 3. Length of the predator fish Eleginops maclovinus and percentage of frequency of Hemigrapsus crenulatus as prey for different months in the Valdivia River.

\begin{tabular}{lccll}
\hline \multicolumn{1}{c}{ Date } & L $\mathbf{( c m )}$ & $\mathbf{\% ~ F}$ & $\mathbf{\% ~ N}$ & \multicolumn{1}{c}{ Reference } \\
\hline March 2002 & $18-42$ & 4.9 & 0.008 & Pavés et al. (2005) \\
August 2003 & $18-42$ & 9.1 & 0.038 & Pequeño et al. (2010) \\
Nov 2002-Dec. 2003 & $19-79$ & 35.4 & 2.550 & Licandeo et al. (2006) \\
\hline
\end{tabular}

$\mathrm{L}=$ Length; $\mathrm{F}=$ Frecuency; $\mathrm{N}=$ Number.

Table 4. Proximal composition of the flesh of the structures of the body and organs of species in the Brachyura family (average \pm standard deviation).

\begin{tabular}{|c|c|c|c|c|c|}
\hline $\begin{array}{l}\text { Species and } \\
\text { Origin }\end{array}$ & Organ or Structure & $\begin{array}{c}\text { Crude } \\
\text { protein }(\%)\end{array}$ & $\begin{array}{c}\text { Crude lipids } \\
(\%)\end{array}$ & $\begin{array}{l}\text { Ash } \\
(\%)\end{array}$ & Reference \\
\hline C. pagurus $($ q)* & M & $16.4 \pm 4.2$ & $0.3 \pm 0.1$ & $2.1 \pm 0.2$ & Barrento et al. (2010) \\
\hline \multirow[t]{2}{*}{ Scotland } & $\mathrm{H}$ & $12.2 \pm 1.6$ & $10.2 \pm 3.6$ & $3.0 \pm 0.4$ & \\
\hline & G & $25.5 \pm 0.0$ & $3.1 \pm 0.5$ & $1.6 \pm 0.0$ & \\
\hline C. pagurus $\left(ठ^{\Uparrow}\right)^{*}$ & M & $20.5 \pm 1.7$ & $0.2 \pm 0.1$ & $1.9 \pm 0.1$ & \\
\hline \multirow[t]{2}{*}{ Scotland } & $\mathrm{H}$ & $13.3 \pm 1.9$ & $12.2 \pm 3.4$ & $5.0 \pm 1.2$ & \\
\hline & G & $13.1 \pm 0.0$ & $0.9 \pm 0.0$ & $2.7 \pm 0.0$ & \\
\hline E. sinensis ${ }^{\#}\left(ठ^{\pi}\right)$ & Flesh $\mathrm{Ch}, \mathrm{P}$ and $\mathrm{A}$ & $18.9 \pm 0.5$ & $0.9 \pm 0.1$ & $1.39 \pm 0.01$ & Chen et al. (2007) \\
\hline China & $\mathrm{Ve}(\mathrm{H}$ and $\mathrm{G})$ & $12.5 \pm 0.4$ & $20.2 \pm 0.1$ & $1.90 \pm 0.08$ & \\
\hline M. brachydactyla ${ }^{+}$ & M & $15.7 \pm 3.0$ & $0.32 \pm 0.06$ & $2.55 \pm 0.05$ & Marques et al. (2010) \\
\hline \multirow[t]{2}{*}{ (q) Scotland } & $\mathrm{H}$ & $13.7 \pm 1.4$ & $7.08 \pm 0.75$ & $3.14 \pm 0.27$ & \\
\hline & G & $24.1 \pm 1.7$ & $1.36 \pm 0.28$ & $1.62 \pm 0.05$ & \\
\hline C. maenas $^{\circ}$ & Flesh Ch and the body & $80.9 \pm 0.5$ & $3.8 \pm 0.1$ & - & Naczk et al. (2004) \\
\hline Canada & $\mathrm{E}$ & $7.06 \pm 0.38$ & $0.38 \pm 0.03$ & - & \\
\hline E. sinensis ${ }^{\circ}$ & $\mathrm{H}$ & $22.7 \pm 1.7$ & $59.9 \pm 7.9$ & - & Chang et al. (2017) \\
\hline ( + normal) China & $\mathrm{O}$ & $60.5 \pm 1.0$ & $31.6 \pm 1.0$ & - & \\
\hline E. sinensis ${ }^{\circ}$ & $\mathrm{H}$ & $39.8 \pm 3.13$ & $36.5 \pm 3.3$ & - & \\
\hline ( + precocious) & $\mathrm{O}$ & $62.2 \pm 0.7$ & $30.3 \pm 0.7$ & - & \\
\hline \multicolumn{6}{|l|}{ China } \\
\hline C. mediterraneus ${ }^{\circ}$ & $\mathrm{H}$ & $13.0 \pm 0.6 \mathrm{~m}$ & $21.9 \pm 0.5$ & - & Cherif et al. (2008) \\
\hline Tunisia & Flesh Ch & $17.8 \pm 0.9$ & $0.85 \pm 0.05$ & - & \\
\hline C. sapidus $\mathrm{Cuba}$ & $\mathrm{C}$ & $19.0 \pm 3.0$ & - & $31.0 \pm 1.0$ & $\begin{array}{l}\text { García Alonso and } \\
\text { Oviedo Vega (1990) }\end{array}$ \\
\hline C. sapidus & Flesh Ch & $15.0 \pm 0.03$ & $0.64 \pm 0.01$ & $1.39 \pm 0.02$ & Gökoðlu and \\
\hline Turkey & Flesh body & $14.7 \pm 0.01$ & $0.8 \pm 0.02$ & $1.89 \pm 0.08$ & Yerlikaya (2003) \\
\hline P. pelagicus & Flesh Ch & $21.5 \pm 0.3$ & $0.81 \pm 0.1$ & $2.5 \pm 0.01$ & \\
\hline Turkey & Flesh body & $22.6 \pm 1.0$ & $1.21 \pm 0.02$ & $2.24 \pm 0.02$ & \\
\hline
\end{tabular}

*g per $100 \mathrm{~g}$ sample in dry weight; ${ }^{\circ}$ percentage based on dry weight; ${ }^{*}$ percentage based on wet weight; ${ }^{+} \mathrm{g}$ per $100 \mathrm{~g}$ sample in wet weight; $\mathrm{A}=$ abdomen; $\mathrm{C}=$ cephalthorax; $\mathrm{E}=$ exoskeleton; $\mathrm{G}=$ gonads; $\mathrm{H}=$ hepatopancreas; $\mathrm{M}=$ muscle; $\mathrm{O}=$ ovary; $\mathrm{P}=$ pereiopods; $\mathrm{Ch}=$ chelipods; $\mathrm{Ve}=$ edible viscera $;$ C. pagurus $=$ Cancer pagurus $;$ E. sinensis $=$ Eriocheir sinensis $;$ M. brachydactyla $=$ Maja brachydctyla; C. maenas $=$ Carcinus maenas C. mediterraneus $=$ Carcinus mediterraneus; C. sapidus $=$ Callinectes sapidus; P. pelagicus $=$ Portunus pelagicus.

that allow the nutrients that it contains to become more bio accessible and bioavailable for the fish.

Given that $H$. crenulatus turned out to be one of the main prey of E. maclovinus in Puerto Cisnes, it would seem to obtain the main nutrients required to meet its needs based on consumption of this species. These nutrients include the high amount of ash found, which would provide a high contribution of minerals. However, the bioavailability of those minerals would be low because the exoskeleton, which is where they are mainly found, is not digested a great deal in the intestine of the fish. Based on the proximal analysis, the results obtained in this study could serve as a point of departure for estimating the needs of the species in their juvenile stage. This statement would be more robust based on Sa et al. (2014), who determined that the protein requirement of juveniles of the species would be $10 \%$ to meet metabolic needs and $35 \%$ to optimize growth. This would fall within the range of protein found in H. crenulatus (32\%). Additionally, Oyarzún et al. (2019) has suggested reducing the percentage of lipids in the diet of E. maclovinus due to the presence of fatty liver in juveniles of this species fed with a commercial diet with 
a lipid percentage of $20 \%$. The presence of fatty liver can have a negative effect on the physiology of E. maclovinus, so it would be appropriate to reduce lipid levels taking into account the lipid values obtained in the present study for $H$. crenulatus. Based on this information, it is reasonable that E. maclovinus juveniles would require a low level of lipids, but they would have to be good quality. These are mainly comprised of PUFAs, which have been described as having a series of benefits for fish such as improving growth and larval survival, decreasing the incidence of malformations, improving reproductive performance and increasing immune response (Roo et al., 2009; Chen et al., 2016; Norberg et al., 2017).

\subsection{Fatty acid profile of $H$. crenulatus}

In regard to the fatty acid profile determined for the full body of specimens of $H$. crenulatus captured during the summer of 2018 in Puerto Cisnes, the results obtained are: SAFAs: $29.5 \%$, MUFAs: $29.7 \%$, PUFAs: $40.7 \%$. When compared to those described for structures or organs of other species from the Brachyura infraorder (Table 5), there is a large amount of variation (SAFAs: $16.7-45.7 \%$, MUFAs: $22.7-50.1 \%$, PUFAs: $6.5-52.2 \%$ ) given that the composition of fatty acids would vary based on the feeding habits, age and sex of each individual as well as the season, salinity and temperature in which each species lives (Barrento et al., 2010). This would suggest that the fatty acid profile described for summer could change over the course of the year.

Regardless of the variability found in the results obtained and those described in the literature, the high percentage of polyunsaturated fatty acids found suggests that $H$. crenulatus has a higher level of lipids than other Brachyura, that are of very good quality, particularly given that the PUFAs include a good proportion of EPA $(18.8 \%)$ and DHA (5.5\%) fatty acids, which are known to play important biological roles (precursor to bioactive compounds, structural maintenance and functional integrity of cellular membranes in fish, important for the normal development of neural function and others) (Bell et al., 1995; Sargent et al., 2002). There are two potential explanations for the high concentration of PUFAs. The first is that $H$. crenulatus obtains them from its diet (detritus, fellow members of its species, fish, dead crustaceans, and the macroalgae Ulva sp.) (Retamal, 1969). The second is that they can biosynthesize, which would be possible in function of that which was described by Monroig et al. (2013), who state that the species Eriocheir sinensis, which belongs to the same Brachyura family, has a desaturase that would allow for biosynthesis of PUFAs. However, studies must be conducted to corroborate biosynthesis of PUFAs in $H$. crenulatus.

Table 5. Composition of saturated fatty acids (SAFAs), monounsaturated fatty acids (MUFAs), polyunsaturated fatty acids (PUFAs), eicosapentaenoic acid (EPA) and docosahexaenoic acid (DHA) of some organs and structures of Brachyura species (average \pm standard deviation).

\begin{tabular}{|c|c|c|c|c|c|c|c|}
\hline Species and origin & $\begin{array}{l}\text { Organ or } \\
\text { Structure }\end{array}$ & $\begin{array}{c}\text { SAFAs } \\
(\%) \\
\end{array}$ & $\begin{array}{c}\text { MUFAs } \\
(\%)\end{array}$ & $\begin{array}{c}\text { PUFAs } \\
(\%)\end{array}$ & $\operatorname{EPA}(\%)$ & DHA (\%) & Reference \\
\hline C. pagurus $(+)^{\circ}$ & M. & $17.4 \pm 0.9$ & $30.8 \pm 1.7$ & $48.4 \pm 2.7$ & $21.3 \pm 2.5$ & $10.9 \pm 1.5$ & et al. \\
\hline \multirow[t]{2}{*}{ Scotland } & H. & $21.8 \pm 2.6$ & $46.3 \pm 5.3$ & $24.2 \pm 4.2$ & $5.5 \pm 1.5$ & $6.5 \pm 2.1$ & (2010) \\
\hline & G. & $17.6 \pm 1.8$ & $34.3 \pm 0.7$ & $43.2 \pm 2.4$ & $13.9 \pm 0.4$ & $14.2 \pm 1.6$ & \\
\hline C. pagurus $(\overbrace{}^{\pi})^{\circ}$ & M. & $16.7 \pm 1.0$ & $30.9 \pm 1.5$ & $48.9 \pm 1.8$ & $19.5 \pm 2.3$ & $11.5 \pm 1.3$ & \\
\hline \multirow[t]{2}{*}{ Scotland } & H. & $20.5 \pm 1.8$ & $38.8 \pm 4.5$ & $32.8 \pm 2.4$ & $7.4 \pm 1.7$ & $10.4 \pm 1.3$ & \\
\hline & G. & $16.6 \pm 0.9$ & $32.2 \pm 2.1$ & $48.6 \pm 3.6$ & $19.7 \pm 0.9$ & $15.5 \pm 0.9$ & \\
\hline $\begin{array}{l}\text { E. sinensis }\left(\jmath^{\top}\right)^{\circ} \\
\text { China }\end{array}$ & E.s. & 24.91 & 49.81 & 23.87 & $2.17 \pm 0.1$ & $2.85 \pm 0.1$ & $\begin{array}{l}\text { Chen et al. } \\
\text { (2007) }\end{array}$ \\
\hline M. brachydactyla ${ }^{\circ}$ & M. & $20.8 \pm 0.7$ & $22.7 \pm 0.7$ & $52.2 \pm 0.7$ & $22.1 \pm 1.2$ & $12.5 \pm 0.4$ & Marques et al. \\
\hline \multirow[t]{2}{*}{ (q) Scotland } & H. & $45.7 \pm 2.8$ & $38.6 \pm 2.6$ & $6.5 \pm 0.9$ & $0.36 \pm 0.2$ & $0.63 \pm 0.2$ & (2010) \\
\hline & G. & $23.0 \pm 0.7$ & $28.0 \pm 0.3$ & $42.9 \pm 1.0$ & $15.1 \pm 0.5$ & $12.2 \pm 0.5$ & \\
\hline $\begin{array}{l}\text { C. maenas } \\
\text { Canada }\end{array}$ & $\begin{array}{l}\text { Ch. flesh and } \\
\text { body }\end{array}$ & 19.0 & 25.7 & 48.4 & 25.1 & 11.9 & $\begin{array}{l}\text { Naczk et al. } \\
\text { (2004) }\end{array}$ \\
\hline C. mediterraneus ${ }^{\circ}$ & Ch. flesh & $23.1 \pm 0.5$ & $24.0 \pm 0.7$ & $36.1 \pm 0.9$ & $8.9 \pm 0.4$ & $10.5 \pm 0.9$ & Cherif et al. \\
\hline Tunisia & H. & $26.2 \pm 0.5$ & $24.1 \pm 0.7$ & $42.9 \pm 0.9$ & $11.0 \pm 0.4$ & $11.4 \pm 0.9$ & (2008) \\
\hline M. magister $(+)^{*}$ & G. & 22.3 & 46.1 & 31.6 & 15.4 & 12.7 & Allen (1971) \\
\hline \multirow[t]{4}{*}{ United States } & E. & 23.2 & 47.3 & 29.5 & 16.8 & 8.8 & \\
\hline & H. & 22.1 & 50.1 & 27.8 & 12.3 & 10.1 & \\
\hline & V. & 21.8 & 45.8 & 32.4 & 20.2 & 8.7 & \\
\hline & M. & 20.6 & 28.1 & 51.3 & 34.2 & 13.9 & \\
\hline
\end{tabular}

${ }^{\circ}$ Total percentage of fatty acids identified; ${ }^{*} \mathrm{~g}$ of fatty acids per $100 \mathrm{~g}$ of total fatty acids; $\mathrm{E}=$ exoskeleton; E.s. $=$ edible structures; $\mathrm{G}=$ gonads; $\mathrm{H}$ = hepatopancreas; $\mathrm{M}=$ muscle; $\mathrm{Ch}=$ chelipeds; $\mathrm{V}=$ viscera; $C$. pagurus $=$ Cancer pagurus; E. sinensis = Eriocheir sinensis; M. brachydactyla = Maja brachydactyla $;$ C. maenas = Carcinus maenas; C. mediterraneus $=$ Carcinus mediterraneus; M. magister $=$ Metacarcinus magister . 
As conclusion, the fully body of specimens of $H$. crenulatus collected during the summer in Puerto Cisnes are mainly composed of ash (35.9\%) and proteins (32.2\%), and to a lesser extent by carbohydrates (19.8\%), crude fiber $(8.5 \%)$ and lipids (3.6\%). Its fatty acid composition is $40.7 \%$ PUFAs, 29.7\% MUFAs and 29.5\% SAFAs. H. crenulatus has highest level of proteins, lipids and PUFAs among the species of the Brachyura infraorder.

\section{Acknowledgements}

The present investigation was carried out in the facilities of the laboratory of nutrition and physiology of fish of the Universidad Católica de Temuco and was part of the work of G.F.M. to fulfill the requirements for the degree of Engineer in Aquaculture (Ingeniero en Acuicultura) issued by the same university, and the project MECESUP UCT 0804, also the authors express their gratitude to M.I and S.M.A. for their valuable suggestions for improve the manuscript.

\section{References}

ADEYEYE, E.I., 2002. Determination of the chemical composition of the nutritionally valuable parts of male and female common West African fresh water crab Sudananautes africanus africanus. International Journal of Food Sciences and Nutrition, vol. 53, no. 3, pp. 189-196. http://dx.doi.org/10.1080/09637480220132805. PMid:11951582.

ALLEN, W.V., 1971. Amino acid and fatty acid composition of tissues of the dungeness crab (Metacarcinus magister). Journal of the Fisheries Research Board of Canada, vol. 28, no. 8, pp. 1191-1195. http://dx.doi.org/10.1139/f71-175.

ASSOCIATION OF OFFICIAL ANALYTICAL CHEMISTS AOAC, 1993. Official methods of analysis. 14th ed. Washington: AOAC.

ASSOCIATION OF OFFICIAL ANALYTICAL CHEMISTS AOAC, 1995. Official methods of analysis 16th ed. Washington: AOAC.

BARRENTO, S., MARQUES, A., TEIXEIRA, B., MENDES, R., BANDARRA, N., VAZ-PIRES, P. and NUNES, M.L., 2010. Chemical composition, cholesterol, fatty acid and amino acid in two populations of brown crab Cancer pagurus: ecological and human health implications. Journal of Food Composition and Analysis, vol. 23, no. 7, pp. 716-725. http://dx.doi.org/10.1016/j. jfca.2010.03.019.

BELL, J.G., CASTELL, J.D., TOCHER, D.R., MACDONALD, F.M. and SARGENT, J.R., 1995. Effect of different dietary arachidonic acid: docosahexaenoic acid ratios on phospholipid fatty acid compositions and prostglandin production in juvenile turbot Scophthalmus maximus. Fish Physiology and Biochemistry, vol. 14, no. 2, pp. 139-151. http://dx.doi.org/10.1007/BF00002457. PMid:24197361.

BRICKLE, P., LAPTIKHOVSKY, V. and ARKHIPKIN, A., 2005. Reproductive strategy of a primitive temperate notothenioid Eleginops maclovinus. Journal of Fish Biology, vol. 66, no. 4, pp. 1044-1059. http://dx.doi.org/10.1111/j.0022-1112.2005.00663.x.

BUSCHMANN, A., CABELLO, F., YOUNG, K., CARVAJAL, J., VARELA, D.A. and HENRÍQUEZ, L., 2009. Salmon aquaculture and coastal ecosystem health in Chile: analysis of regulations, environmental impacts and bioremediation systems. Ocean and Coastal Management, vol. 52, no. 5, pp. 243-249. http://dx.doi. org/10.1016/j.ocecoaman.2009.03.002.

CEBALLOS, S.G., LESSA, E.P., LICANDEO, R. and FERNÁNDEZ, D.A., 2016. Genetic relationships between Atlantic and Pacific populations of the notothenioid fish Eleginops maclovinus: the footprints of Quaternary glaciations in Patagonia. Heredity, vol. 116, no. 4, pp. 372-377. http://dx.doi.org/10.1038/hdy.2015.106. PMid:26696136.

CHANG, G., WU, X., CHENG, Y., ZENG, C. and YU, Z., 2017. Reproductive performance, offspring quality, proximate and fatty acid composition of normal and precocious Chinese mitten crab Eriocheir sinensis. Aquaculture (Amsterdam, Netherlands), vol. 469, pp. 137-143. http://dx.doi.org/10.1016/j.aquaculture.2016.11.025.

CHEN, C., SUN, B., GUAN, W., BI, Y., LI, P., MA, J., CHEN, F., PAN, Q. and XIE, Q., 2016. N-3 essential fatty acids in Nile tilapia, Oreochromis niloticus: effects of linolenic acid on nonspecific immunity and anti-inflammatory responses in juvenile fish. Aquaculture, vol. 450, no. 1, pp. 250-257. http://dx.doi. org/10.1016/j.aquaculture.2015.08.005.

CHEN, D., ZHANG, M. and SHRESTHA, S., 2007. Compositional characteristics and nutritional quality of Chinese mitten crab (Eriocheir sinensis). Food Chemistry, vol. 103, no. 4, pp. 13431349. http://dx.doi.org/10.1016/j.foodchem.2006.10.047.

CHERIF, S., FRIKHA, F., GARGOURI, Y. and MILED, N., 2008. Fatty acid composition of green crab (Carcinus mediterraneus) from the Tunisian mediterranean coasts. Food Chemistry, vol. 111, no. 4, pp. 930-933. http://dx.doi.org/10.1016/j.foodchem.2008.05.007.

CUMILLAF, J.P., BLANC, J., PASCHKE, K., GEBAUER, P., DÍAZ, F., RE, D., CHIMAL, M.E., VÁSQUEZ, J. and ROSAS, C., 2016. Thermal biology of the sub-polar-temperate estuarine crab Hemigrapsus crenulatus (Crustacea: Decapoda: Varunidae). Biology Open, vol. 5, no. 3, pp. 220-228. http://dx.doi.org/10.1242/ bio.013516. PMid:26879464.

DANTAGNAN, P., DOMINGUEZ, A., BORQUEZ, A., ALCAINO, J., PAVEZ, C. and HERNANDEZ, A., 2012. Influence of $\alpha$-tocopherol on arachidonic acid deposition and peroxidation in Atlantic salmon (Salmo salar) fingerlings. Latin American Journal of Aquatic Research, vol. 40, no. 3, pp. 562-577. http:// dx.doi.org/10.3856/vol40-issue3-fulltext-6.

DE LOS RÍOS, P., FIGUEROA-MUÑOZ, G., RETAMAL, M.A. and VEGA-AGUAYO, R., 2019. Corrigendum to threerecent papers in Crustaceana regarding the Chilean brachyuran Hemigrapsus crenulatus. Crustaceana, vol. 92, no. 7, pp. 895-896. http://dx.doi. org/10.1163/15685403-00003922.

DEGUARA, S., 1997. Evaluation of different pressed and extruded fish meal based diets on the growth of gilthead sea bream, Sparus aurata. Cahiers Options Méditerranée, vol. 22, pp. 123-139.

FIGUEROA-MUÑOZ, G. and DE LOS RÍOS, P., 2018. Presence of Hemigrapsus crenulatus (Decapoda, Brachyura, Varunidae) is stomach contents of Eleginops maclovinus (Cuvier, 1830) (Pisces)

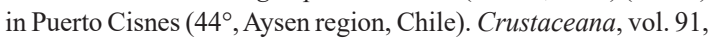
no. 7, pp. 463-469. http://dx.doi.org/10.1163/15685403-00003922.

FOLCH, J., LEES, M. and SLOANE-STANLEY, G.H.S., 1957. A simple method for the isolation and purification of total lipids from animal tissues. The Journal of Biological Chemistry, vol. 226, no. 1, pp. 497-509. PMid:13428781. 
FORTT, A., CABELlO, F. and BUSCHMANN, A., 2007. Residues of tetracycline and quinolones in wild fish living around a salmon aquaculture center in Chile. Revista Chilena de Infectologia, vol. 24, no. 1, pp. 14-18. http://dx.doi.org/10.4067/ S0716-10182007000100002. PMid:17369965.

GACITÚA, S., OYARZÚN, C. and VEAS, R., 2008. Morphometric and meristic multivariate analysis in patagonian blennie Eleginops maclovinus (Cuvier, 1830). Revista de Biología Marina y Oceanografia, vol. 43, no. 3, pp. 491-500. http://dx.doi.org/10.4067/ S0718-19572008000300008.

GARCÍA ALONSO, I. and OVIEDO VEGA, D., 1990. Characterization of the main sources of chitin in Cuba. Journal of Thermal Analysis, vol. 36, no. 3, pp. 891-899. http://dx.doi. org/10.1007/BF01904625.

GÖKOĐLU, N. and YERLIKAYA, P., 2003. Determination of proximate composition and mineral contents of blue crab (Callinectes sapidus) and swim crab (Portunus pelagicus) caught off the Gulf of Antalya. Food Chemistry, vol. 80, no. 4, pp. 495-498. http:// dx.doi.org/10.1016/S0308-8146(02)00318-7.

GOSZTONYI, A., 1974. Edad y crecimiento del "Robalo" Eleginops maclovinus (Osteichthyes, Nototheniidae) en aguas de la ría Deseado y sus adyacencias. Physis, vol. 33, pp. 1-8.

GUZMÁN, L. and CAMPODÓNICO, I., 1973. Algunos aspectos de la biología de Eleginops maclovinus (Cuv. y Val. 1830), con especial referencia a su morfometría, caracteres merísticos y alimentación. Anales del Instituto de la Patagonia, vol. 4, pp. 343-371

LICANDEO, R.R., BARRIENTOS, C.A. and GONZÁLEZ, M.T., 2006. Age, growth rates, sex change and feeding habits of notothenioid fish Eleginops maclovinus from the central-southern Chilean coast. Environmental Biology of Fishes, vol. 77, no. 1, pp. 51-61. http://dx.doi.org/10.1007/s10641-006-9054-z.

MARQUES, A., TEIXEIRA, B., BARRENTO, S., ANACLETO, P., CARVALHO, M.L. and NUNES, M.L., 2010. Chemical composition of Atlantic spider crab Maja brachydactyla: human health implications. Journal of Food Composition and Analysis, vol. 23, no. 3, pp. 230-237. http://dx.doi.org/10.1016/j.jfca.2009.10.007.

MARTIN, J.P. and BASTIDA, R., 2008. Contribution of benthic communities to the diet of the Patagonian blenny (Eleginops maclovinus) at Ría Deseado (Santa Cruz, Argentina). Latin American Journal of Aquatic Research, vol. 36, no. 1, pp. 1-13. http://dx.doi.org/10.3856/vol36-issue1-fulltext-1.

MAYNARD, L.A., LOOSLI, J.K., HINTZ, H.F. and WARNER, R.G., 1979. Animal nutrition. New York: McGrawHill.

MCLAY, C.L., HINNENDAEL, F., LAVERY, S. and RIQUELMEBUGUEÑO, R., 2011. Morphological and molecular comparison of Hemigrapsus crenulatus (Milne Edwards, 1837) (Brachyura: Varunidae) from New Zealand and Chile: was Miss Rathbun right? Journal of Crustacean Biology, vol. 31, no. 4, pp. 582-589. http://dx.doi.org/10.1651/11-3494.1.

MONROIG, Ó., TOCHER, D.R. and NAVARRO, J.C., 2013. Biosynthesis of polyunsaturated fatty acids in marine invertebrates: recent advances in molecular mechanisms. Marine Drugs, vol. 11, no. 10, pp. 3998-4018. http://dx.doi.org/10.3390/md11103998. PMid:24152561.

MORRISON, W.R. and SMITH, L.M., 1964. Preparation of fatty acids methyl esters and dimethylacetals from lipids with boron fluoride-methanol. Journal of Lipid Research, vol. 5, pp. 600-608. PMid:14221106.
NACZK, M., WILLIAMS, J., BRENNAN, K., LIYANAPATHIRANA, C. and SHAHIDI, F., 2004. Compositional characteristics of green crab (Carcinus maenas). Food Chemistry, vol. 88, no. 3, pp. 429-434. http://dx.doi.org/10.1016/j.foodchem.2004.01.056.

NORBERG, B., KLEPPE, L., ANDERSSON, E., THORSEN, A., ROSENLUND, G. and HAMRE, K., 2017. Effect of dietary arachidonic acid on the reproductive physiology of female atlantic $\operatorname{cod}$ (Gadus morhua). General and Comparative Endocrinology, vol. 250, no. 1, pp. 21-35. http://dx.doi.org/10.1016/j.ygcen.2017.05.020. PMid:28576420.

OYARZÚN, R., MARTINEZ, D., SOTO-DÁVILA, M., MUÑOZ, J.L.P., DANTAGNAN, P. and VARGAS-CHACOFF, L., 2019. Effect of ration level on growth performance, body composition, intermediary metabolism and serum parameters in juvenile Patagonian blennie Eleginops maclovinus. Comparitive Biochemistry and Physiology Part A Molecular Integrated Physiology, vol. 230, pp. 122-130. http://dx.doi.org/10.1016/j. cbpa.2019.01.013. PMid:30703559.

OYARZÚN, R., MUÑOZ, J.L., PONTIGO, J.P., MORERA, F.J. and VARGAS-CHACOFF, L., 2018. Effects of acclimation to high environmental temperatures on intermediary metabolism and osmoregulation in the sub-Antarctic notothenioid Eleginops maclovinus. Marine Biology, vol. 165, no. 1, pp. 1-15. http:// dx.doi.org/10.1007/s00227-017-3277-8.

PAVÉS, H., PEQUEÑO, G., BERTRÁN, C. and VARGASCHACOFF, L., 2005. Limnetic feeding in Eleginops maclovinus (Valenciennes, 1830) in the Valdivia River, Chile. Interciencia, vol. 30, no. 3, pp. 120-125.

PEQUEÑO, G., 1979. Antecedentes alimentarios de Eleginops maclovinus (Valenciennes, 1830) (Teleostomi Nototheniidae), en Mehuín, Chile. Acta Zoológica Lilloana, vol. 35, pp. 207-230.

PEQUEÑO, G., PAVÉS, H., BERTRÁN, C. and VARGASCHACOFF, L., 2010. Seasonal limnetic feeding regime of the "robalo" Eleginops maclovinus (Valenciennes 1830), in the Valdivia river, Chile. Gayana, vol. 74, no. 1, pp. 47-56. http:// dx.doi.org/10.4067/S0717-65382010000100008.

RETAMAL, M.A. and MOYANO, H.I., 2010. Zoogeografía de los crustáceos decápodos chilenos marinos y dulceacuícola. Latin American Journal of Aquatic Research, vol. 38, no. 3, pp. 302-328. http://dx.doi.org/10.3856/vol38-issue3-fulltext-1.

RETAMAL, M.A., 1969. Hemigrapsus crenulatus (H. Milne Edwards, 1837), en el estero Lenga (Crustacea, Decapoda, Grapsidae). Boletín de la Sociedad de Biología de Concepción, vol. 13, pp. 281-309.

ROO, F.J., HERNÁNDEZ-CRUZ, C.M., SOCORRO, J.A., FERNÁNDEZ-PALACIOS, H., MONTERO, D. and IZQUIERDO, M.S., 2009. Effect of DHA content in rotifers on the occurrence of skeletal deformities in red porgy Pagrus pagrus (Linnaeus, 1758). Aquaculture, vol. 287, no. 1-2, pp. 84-93. http://dx.doi. org/10.1016/j.aquaculture.2008.10.010.

SA, R., GAVILÁN, M., RIOSECO, J.M., LLANCABURE, A., VARGAS-CHACOFF, L., AUGSBURGER, A. and BAS, F., 2014. Dietary protein requirement of Patagonian blennie (Eleginops maclovinus, Cuvier 1830) juveniles. Aquaculture, vol. 428/429, pp. 125-134. http://dx.doi.org/10.1016/j.aquaculture.2014.02.017.

SARGENT, J.R., TOCHER, D.R. and BELL, J.G., 2002. The lipids. In: J.E. HALVER and R.W. HARDY, eds. Fish nutrition. San Diego: Academic Press, pp. 181-257. 
SIFA, L., WANQI, C., SHUMING, Z., CHENHONG, L., JINLIANG, Z. and CHENGHUI, W., 2000. Quality analysis of Chinese mitten crab Eriocheir sinensis in Yangchenghu Lake. Journal of Fisheries Sciences of China, vol. 7, no. 3, pp. 71-74.

TOCHER, D.R., 2010. Fatty acid requirements in ontogeny of marine and freshwater fish. Aquaculture Research, vol. 41, no. 5, pp. 717-732. http://dx.doi.org/10.1111/j.1365-2109.2008.02150.x.

URBINA, M., PASCHKE, K., GEBAUER, P. and CHAPARRO, O.R., 2010. Physiological energetics of the estuarine crab Hemigrapsus crenulatus (Crustacea: Decapoda: Varunidae): responses to different salinity levels. Journal of Marine Biological Assocciation UK., vol. 90, no. 2, pp. 267-273. http://dx.doi. org/10.1017/S0025315409990889.

URZÚA, A. and URBINA, M.A., 2017. Ecophysiological adaptations to variable salinity environments in the crab Hemigrapsus crenulatus from the Southeastern Pacific coast: sodium regulation, respiration and excretion. Comparative Biochemistry and Physiology. Part A, Molecular \& Integrative Physiology, vol. 210, pp. 35-43. http://dx.doi.org/10.1016/j.cbpa.2017.05.010. PMid:28558963.

VALDEBENITO ISLER, I., FIGUEROA VILLALOBOS, E., SANDOVAL, L., CONTRERAS MELLADO, P., SÁNCHEZ CAAMAÑO, J.C., AVENDAÑO, J.F. and RISOPATRÓN, J., 2018. Characterization of first blastomeres in patagonian blennie (Eleginops maclovinus) (Perciformes: eleginopidae). Zygote, vol. 26, no. 6, pp. 443-448. http://dx.doi.org/10.1017/ S0967199418000217. PMid:30516457.
VALDEBENITO ISLER, I., COSSON, J., CONTRERAS, P., SÁNCHEZ, J.C., OLIVEIRA, R.P.S., RISOPATRÓN, J., FARÍAS, J.G. and FIGUEROA, E., 2016. Spermatological research of experimentally farmed Patagonian blenny (Eleginops maclovinus) (Perciformes: Eleginopsidae) in Chile. Aquaculture Research, vol. 48, no. 8, pp. 4197-4204. http://dx.doi.org/10.1111/are.13240.

VARGAS-CHACOFF, L., MARTÍNEZ, D., OYARZÚN, R., NUALART, D., OLAVARRÍA, V., YÁÑEZ, A., BERTRÁN, C., RUIZ-JARABO, I. and MANCERA, J.M., 2014. Combined effects of high stocking density and Piscirickettsia salmonis treatment on the immune system, metabolism and osmoregulatory responses of the Sub-Antarctic Notothenioid fish Eleginops maclovinus. Fish \& Shellfish Immunology, vol. 40, no. 2, pp. 424-434. http:// dx.doi.org/10.1016/j.fsi.2014.07.024. PMid:25108087.

VARGAS-CHACOFF, L., MONEVA, F., OYARZÚN, R., MARTÍNEZ, D., SAAVEDRA, E., RUIZ-JARABO, I., MUÑOZ, J.L.P., BERTRÁN, C. and MANCERA, J.M., 2016. Metabolic responses to salinity changes in the subantartic notothenioid teleost Eleginops maclovinus. Polar Biology, vol. 39, no. 7, pp. 1297-1308. http://dx.doi.org/10.1007/s00300-015-1854-1.

VEGA-AGUAYO, R., FIGUEROA-MUÑOZ, G., RETAMAL, M.A. and DE LOS RÍOS-ESCALANTE, P., 2018. Spatial Distribution and Abundance of Hemigrapsus crenulatus $(\mathrm{H}$. Milne-Edwards, 1837) (Decapoda, Varunidae) in Puerto Cisnes Estuary $\left(44^{\circ} \mathrm{S}\right.$, Aysen region, Chile). Crustaceana, vol. 91, no. 12, pp. 1465-1482. http://dx.doi.org/10.1163/15685403-00003841. 